\title{
Morphometric patterns in assemblages of Cricetid rodents from the Central and Western Cordilleras of Colombia
}

\author{
Edilson Patiño-Castillo ${ }^{1 *}$ and Sergio Solari ${ }^{1,2}$ \\ ${ }^{1}$ Grupo Mastozoología, Universidad de Antioquia, Calle 67 No. 53-108, Medellín. Antioquia, Colombia. Email edipaca1989@ \\ hotmail.com (EPC) \\ ${ }^{2}$ Instituto de Biología de la Universidad de Antioquia. Calle 70 No. 52-21, Medellín, AA 1226. Antioquia, Colombia. Email sergio. \\ solari@udea.edu.co (SS). \\ * Corresponding author
}

The mechanisms that mediate the formation and coexistence of species assemblages have been a historical issue in evolutionary ecology, raising the question of whether these assemblages are shaped at random or are influenced by biotic and abiotic processes. An increasingly popular hypothesis points out that certain patterns or "assemblage rules" determine coexistence patterns within assemblages at a regional or continental scale. Thus, morphological and ecological similarities could influence the degree and intensity of competition between species. Considering the morphology of organisms within an environmental framework, we could assess the morphology and understand the ecological role of a given species within the assemblage. This study assesses the similarities and differences of Andean rodents within local assemblages through a Principal Component Analysis (PCA), using craniodental characters of these species to establish whether the relationships between morphometry and coexistence provide evidence to explain assemblage structure patterns. We measured rodent specimens deposited in the Colección Teriológica of the University of Antioquia, collected from the Western and Central cordilleras of Colombia. We recorded 15 craniodental variables from all specimens, which were analyzed with a PCA to search for a general organization pattern within assemblages. Afterwards, we plotted the scores for principal components 1 and 2 to evidence the separation or clustering of specimens in an Euclidean space. We recorded 424 specimens from 10 genera and 18 species of the family Cricetidae, with the genera Nephelomys and Thomasomys showing the largest number of specimens. In the overall PCA, the first three components account for $85.1 \%$ of the variation, with $63.9 \%$ for PC1. The variables with the greatest contributions to PC1 were ZPW, AW and MFW; to PC2, IFL, ZPW and MFW; and to PC3, IFL, OL and ML. We detected some overlapping and scattering patterns among species at the morphospace defined by PC1 and PC2. We recovered an arrangement of species that shows differences in size and shape between them (as a function of their morphology), as evidenced in the scatter plots for the regional and local analyses. Besides, we did not find a general pattern for the load of variables, although some of these accounted for a larger part of the variation in the overall and local analyses (ZPW, MFW, IFL, ML and RL), indicating the segregation among species. Although the local analyses revealed a similar pattern with these loads changing from site to site, five variables account for the largest variation, what we interpret as a key role to determine the morphometric and/or ecological segregation among species. We believe this first approximation shows the value of ecomorphological studies in understanding patterns of diversity and geographic replacement of species; these patterns should be integrated with analyses of ecological aspects to understand the coexistence of species within local assemblages.

Los mecanismos que intervienen en la formación y coexistencia de ensamblajes de especies han sido un tema histórico en ecología evolutiva, de allí surge la pregunta si los ensamblajes de especies se forman aleatoriamente o si son influenciados por procesos bióticos y abióticos. Una hipótesis de popularidad creciente indica que los patrones de coexistencia en un ensamblaje, tanto a nivel regional como continental, son determinados por ciertos patrones o "reglas de ensamblaje". Así, el grado e intensidad de la competencia entre especies pueden ser influenciados por su similitud morfológica y ecológica. Considerando la morfología de los organismos formando parte de un esquema ambiental podríamos lograr describir dicha morfología y entender la función ecológica de dicha especie al interior del ensamblaje. Este estudio evalúa las similitudes y diferencias en ensamblajes locales de roedores andinos por medio de Análisis de Componentes Principales (ACP), utilizando aspectos de la morfología cráneo-dental de las especies para establecer si las relaciones entre la morfometría y la coexistencia proporcionan evidencia de patrones de estructuración de los ensamblajes. Se midieron especímenes de la Colección Teriológica de la Universidad de Antioquia, provenientes de las Cordilleras Central y Occidental Colombianas. Se usaron 15 medidas craneales para todos los especímenes, realizando luego un ACP para explorar la existencia de un patrón de organización general a nivel de ensamblajes. Por último, se representaron los valores de los componentes principales 1 y 2 en gráficas de dispersión para visualizar la separación y/o aglomeración de especímenes en el espacio euclidiano. Se registraron un total de 424 especímenes pertenecientes a 10 géneros y 18 especies de la familia Cricetidae, con el mayor número de individuos en los géneros Nephelomys y Thomasomys. En el ACP total los primeros tres componentes contienen $85.1 \%$ de la variación, con $63.9 \%$ para el CP1. Las variables que más aportan al CP1 son ZPW, AW y MFW; al CP2, IFL, ZPW and MFW y al CP3, IFL, OL and ML. Se observan algunos patrones de superposición y dispersión de especies en el morfoespacio definido por el CP1 y CP2. Se logró apreciar un arreglo de especies en el cual se encuentran diferencias en tamaño y forma entre las especies (en función de su morfología), esto se evidencia en las gráficas de dispersión tanto del análisis regional como de los análisis locales. Además, no se encontró un patrón definido en las cargas de las variables, aunque algunas aportaron mayor variación en el análisis total y en los individuales (ZPW, MFW, IFL, ML y RL), determinando la segregación entre especies. A pesar de que en los análisis de cada localidad estos aportes se reparten de forma diferente, cinco variables están aportando la mayor variación, por lo que se infiere que serían claves en determinar la separación morfométrica y/o ecológica de las especies. Finalmente, esta primera aproximación muestra la utilidad de estudios ecomorfológicos para entender patrones de diversidad y reemplazo geográfico de especies, los cuales deberían integrarse con análisis de aspectos ecológicos para interpretar su coexistencia en un ensamblaje local.

Key words: Andean rodents; assemblage rules; evolutionary ecology; morphometrics; Principal Component Analysis.

C 2017 Asociación Mexicana de Mastozoología, www.mastozoologiamexicana.org 


\section{Introduction}

The processes that govern the existence and formation of species assemblages have been a recurrent discussion topic in evolutionary ecology (Diamond 1975; Connor and Simberloff 1979; Bowers and Brown 1982, Gotelli and Ellison 2002), raising the questiont of whether the species assemblages (in a broad sense, a phylogenetically related group within a community; see Fauth et al. 1996) are formed at random, or, on the contrary, are determined by biotic and abiotic processes (Arita 1997; Adams 2007). Various authors (Diamond 1975; Bowers and Brown 1982; Patterson 1999; Adams 2007; Gotelli and Ellison 2002) have suggested that the patterns of species coexistence within an assemblage, at the regional and continental levels, do not occur at random but are determined by certain general patterns or "assemblage rules". These rules would favor the co-occurrence of certain species at the local level, or would eventually determine the morphology (for example, the arrangement of sizes) through interspecific competition dynamics (Willig and Moulton 1989; Gotelli and Ellison 2002). As a result, species within some highly diverse communities will display a relatively uniform organization across a size gradient (Willig 1986; Arita 1997; Adams 2007); as a result, morphologically similar species within a trophic guild are unlikely to occupy the same habitat (Bowers and Brown 1982).

As suggested in other studies, interspecific competition may affect morphological patterns through changes in either the organization of sizes or the adjustment of sizes (Bowers and Brown 1982; Willig and Moulton 1989). In the former case, the probability of persistence of a species within an assemblage decreases by the presence of morphologically similar species, while the latter refers to evolutionary changes in a morphological feature of the involved species to minimize competition (Willig and Moulton 1989). In both cases, an in-depth understanding of the role of competition has been restrained by various methodological issues, in particular the determination of the belonging to ecological guilds and the construction of statistically null assemblages (Arita 1997). For example, it has been indicated that the organization or adjustment of sizes could only act at the assemblage level when competition is sufficiently intense and prevalent at the local level (Willig and Moulton 1989).

If the morphology of an organism is considered as part of an environmental mold, we could describe such morphology and understand the ecological role of this species within the assemblage (Ricklefs and Travis 1980; Willig 1986). Multivariate analyses have been used to describe and compare the spatial clustering of species, by representing these within a hyperdimensional Euclidean space, to estimate the ecological structure within the assemblage (Findley 1975; Ricklefs and Travis 1980; Freeman 1981; Willig 1986; James and McCulloch 1990; Arita 1997; PeresNeto et al. 2003). In general, morphometric characters are usually easier to obtain (often from museum specimens or even from publications), simple to estimate, highly replicable, independent of the structure of the habitat, and adequately correlated with resource use (Pizzimenti and De Salle 1980; Ricklefs and Travis 1980; Freeman 1998). In addition, if morphology is not directly related to ecology, multivariate analyses can unveil patterns that are explained based on a theoretical, ecological and evolutionary context (Ricklefs and Travis 1980; Willig 1986).

In the present study, we used a Principal Components Analysis (PCA) to determine the relative importance of variables with respect to each component (Crisci and Lopez-A 1983; James and McCulloch 1990), and use it as an approximate description of the relationships between the units of study (Peres-Neto et al. 2003), or between their ecological roles, if these are determined by the original variables (Pizzimenti and De Salle 1980; Ricklefs and Travis 1980). If such a pattern does exist and is adequately represented in the variables chosen, the major components of the regional and local analyses would be expected to show similar loads for most variables (Ricklefs and Travis 1980; Peres-Neto et al. 2003).

To assess these patterns, this study focuses on cricetid rodents of the Western, Central and Eastern cordilleras of Colombia. Previous studies (Lopez-Arevalo et al. 1993; Gómez-Valencia 2006; Muñoz-Saba et al. 2000; Otarola 2003; Sánchez et al. 2004; Viancha-Sánchez et al. 2012; Sánchez-Giraldo and Díaz-Nieto 2015) agree that the local richness of rodents reaches an average between 9 and 11 species in 8 to 10 genera, and that composition varies according to elevation and geographic region. At the regional scale, more intensive studies in the Andes of Venezuela (Soriano et al. 1999) and Ecuador (Voss 2003) report 10 and 9 genera of rodents, respectively. Although these studies suggest a regional pattern in these assemblages, the morphometric relationships between organisms within these are not analyzed, which would be key in the process of organization and maintenance of assemblages at the local level (Pizzimenti and De Salle 1980; Ricklefs and Travis 1980; Arita 1997). The objective of this study is to evaluate the similarities and differences between local rodent assemblages from morphometric analyses, using craniodental variables of specimens to infer potential patterns of ecological interrelationship between species. In this way, it could be established whether the relationships between morphometry and coexistence provide evidence of assemblage structuring patterns, for example through a regular arrangement of sizes or shapes among species (Pizzimenti and De Salle 1980; Ricklefs and Travis 1980; Arita 1997).

\section{Materials and Methods}

Data collection. We measured specimens deposited in the Colección Teriológica of the University of Antioquia, Colombia, collected from the Andean region (Central and Western Cordilleras), between 2002 and 2014. Some localities were pooled together to avoid losing information for specimens whose specific localities contained low representativeness in terms of number of species. To this end, we took into 
account that the pooled localities belong politically and/or geographically to the same region, from the 2008 map of the Antioquia regions (available at http://www.zonu.com/ detail/2011-08-23-14446/Regiones--de-Antioquia-2008. html), thereby gathering as much information as possible (Table 1). For example, Bello and Girardota were pooled together (Aburrá Norte), while Jardín-Támesis and La Mesenia (both in the Municipality of Jardín) were kept separated for being located in different mountain ranges. In this way, the analyses are based on these regional units (Figure 1).

Taxonomic identification was performed using keys (Weksler and Percequillo 2011; Patton et al. 2015), descriptions (Voss et al. 2002; Pacheco 2003; Percequillo 2003; Voss 2003; Weksler 2006) and reference material from the same collection and the Field Museum of Natural History (Chicago, USA).

Morphological and Morphometric Analyses. We recorded 15 homolog cranial measurements for all specimens (adult males and females), following the specifications of Patton et al. (2000) and Voss et al. (2001). These measures sought to highlight morpho-functional aspects, for example as regard chewing, or resource selection (see Pizzimenti and De Salle 1980; Giménez and Giannini 2011). The measures employed were: condyle-incisor length (CIL), zygomatic width (ZW), mastoid width (MW), minimum interorbital constriction (MIC/LIB), rostral length (RL), nasal length (NL), rostral width $(\mathrm{RW})$, orbital length $(\mathrm{OL})$, diastema length $(\mathrm{DL})$, molarrow length (ML/LM), incisive-foramen length (IFL), palatal bridge length $(\mathrm{PBL})$, alveolar width $(\mathrm{AW})$, mesopterygoid fossa width (MFW), and zygomatic plate width (ZPW/BZP). Measurements were taken with an electronic caliper to the nearest $0.01 \mathrm{~mm}$, and using a stereoscopic microscope in the case of measures requiring greater precision.

Statistical Analyses The original data were log-transformed (log10; using the program PAST) to reduce biases associated with the different magnitudes of variables, approaching a normal distribution of the data (Ricklefs and Travis 1980; Jackson 1993); then a variance-covariance matrix was obtained (James and McCulloch 1990). This matrix was used to conduct a Principal Components Analysis (PCA) to elucidate the variability of variables (characters), measured in terms of their factorial coefficients (loads). In this analysis, eigenvalues represent the sum of the variances of variables for each component, used for determining which components are more important (Jackson 1993); the components with the largest eigenvalues were used to be represented graphically.

In this way, the PCA was used as a screening tool (Norman and Streiner 1996) for the set of all localities (regional analysis), as well as for some localities evaluated individually (local analyses), to allow a comparison between components and their basic parameters, such as eigenvalues, percentages of variation and factorial coefficients. In order to confirm the reliability when choosing the appropriate components in the overall PCA, a 'bootstrap' resampling of 1000 repetitions was conducted (Jackson 1993; Peres-Neto et al. 2003). In addition, it is also expected to organize the variation related to any individual variable. That is, if two or more variables are summarized by the same component, this will indicate that these share similar co-variation patterns, leading to a better interpretation of the relationship (Peres-Neto et al. 2003). Finally, the values of the first principal compo-

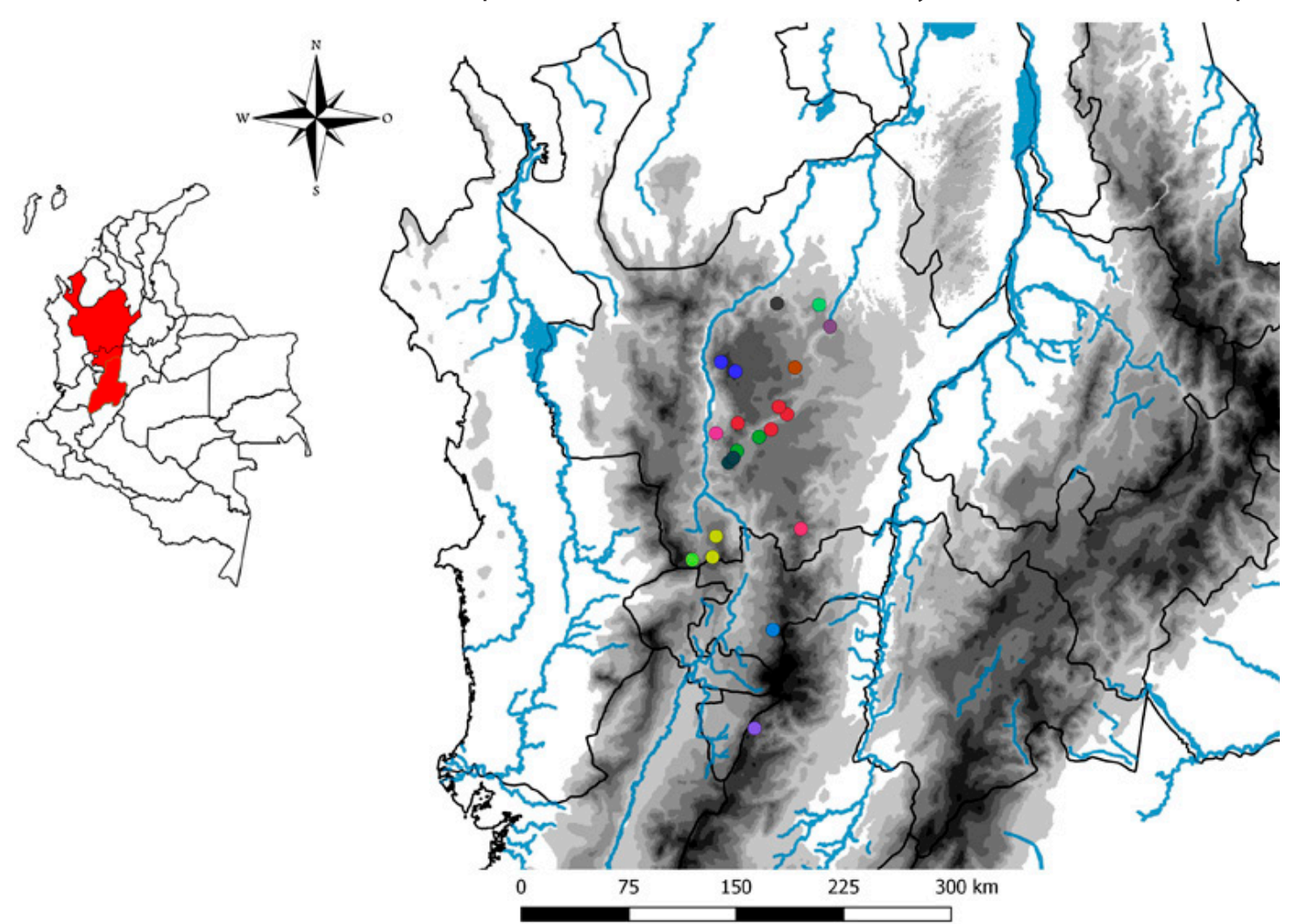

Figure 1. Map of the municipalities in the departments of Antioquia, Caldas and Tolima that included sampling localities for the specimens used in morphometric analyses. 
Table 1. Rodent species included in the analysis with their respective numbers of localities and specimens.

\begin{tabular}{lcc}
\hline \multicolumn{1}{c}{ SPECIES } & \# LOCALITIES & \# SPECIMENS \\
\hline Akodon affinis & 8 & 29 \\
Chilomys instans & 4 & 11 \\
Handleyomys alfaroi & 1 & 2 \\
Handleyomys fuscatus & 2 & 30 \\
Handleyomys intectus & 4 & 38 \\
Melanomys caliginosus & 8 & 37 \\
Microryzomys minutus & 5 & 6 \\
Neacomys tenuipes & 5 & 9 \\
Nephelomys childi & 1 & 15 \\
Nephelomys pectoralis & 12 & 119 \\
Reithrodontomys mexicanus & 5 & 11 \\
Rhipidomys latimanus & 7 & 19 \\
Thomasomys baeops & 2 & 5 \\
Thomasomys cinereiventer & 1 & 4 \\
Thomasomys cinnameus & 2 & 9 \\
Thomasomys contradictus & 6 & 57 \\
Thomasomys nicefori & 4 & 21 \\
Thomasomys popayanus & 2 & 2 \\
TOTAL & $\mathbf{1 8}$ &
\end{tabular}

nents (which represent the greatest variance of the data) are shown in scatter plots obtained with the PAST program (Paleontological Statistics version 3.04; Hammer et al. 2001).

\section{Results}

Number of species and individuals per locality. A total of 424 specimens of Andean rodents were recorded, belonging to 10 genera and 18 species of the family Cricetidae (Sigmodontinae): Akodon, Chilomys, Handleyomys, Melanomys, Microryzomys, Neacomys, Nephelomys, Reithrodontomys, Rhipidomys and Thomasomys (Figure 2), of which Thomasomys, Handleyomys and Nephelomys were the most diverse ones, with six, three and two species, respectively, while the rest recorded a single species each. The genus with the largest number of individuals was Nephelomys with 134 specimens, followed by Thomasomys with 98 specimens. The least represented genera were Neacomys and Microryzomys, with 9 and 6 specimens, respectively (Table 1).

The specimens analyzed were obtained from different localities in the departments of Antioquia, Caldas and Tolima (Table 2), Antioquía being the most important one for its larger number of localities. On the other hand, the comparisons between assemblages were conducted using five localities that showed a high representativeness of individuals and species (see Table 2), as the availability of individuals was restricted in some localities where samples were not rigorous or species were rare. This sampling at different localities and formations allows a reliable approximation of the regional assemblage, as well as an additional level of analysis in the comparison of the relevance of the morphological variables included.

Principal Components Analysis (PCA). The general PCA reveals that the first three components account for $85.2 \%$ of the total variation, with $63.9 \%$ for $\mathrm{CP} 1,11.1 \%$ for $\mathrm{CP} 2$ and $10.1 \%$ for CP3 (Table 3 ). This same table shows quan- titatively the values of the loads contributed by variables to each component; the most important variables for $\mathrm{CP} 1$ were ZPW, AW, and MFW (all with a positive load); for CP2 were IFL, ZPW (negative load) and MFW; and for CP3 were IFL, OL and ML (all with a positive load).

A scatter plot shows $75.1 \%$ of this variation (Figure 3), which, together with the characterization of the principal components $\mathrm{CP} 1$ and $\mathrm{CP} 2$ along with the contribution of the different variables (Table 3), corresponds to the analysis of the regional pattern of the Andean rodent assemblage throughout the study area, providing a reference point for analyzing individual assemblages.

The arrangement of clusters of species (Figure 3) allow defining some morphometric groups based on their limited or null overlap in the space defined by components 1 and 2. These would correspond to: (A) small and delicate, located in quadrant III (M. minutus, N. tenuipes, and R. mexicanus); (B) small, in quadrant II (A. affinis, R. latimanus, T. baeops, and T. cinnameus); (C) medium-sized, in quadrant III (C. instans, H. alfaroi, H. fuscatus, H. intectus, and M. caliginosus); (D) large and delicate, quadrants I and II (T. cinereiventer and T. contradictus); and (E) large, in quadrants I (T. nicefori and T. popayanus) and IV (N. childi and N. pectoralis). To help differentiate these patterns, Figure 4 shows some skulls of representative species within each morphotype.

On the other hand, to analyze the representativeness of the observed patterns (morphogroups), analyses were performed with the data from individual localities that showed

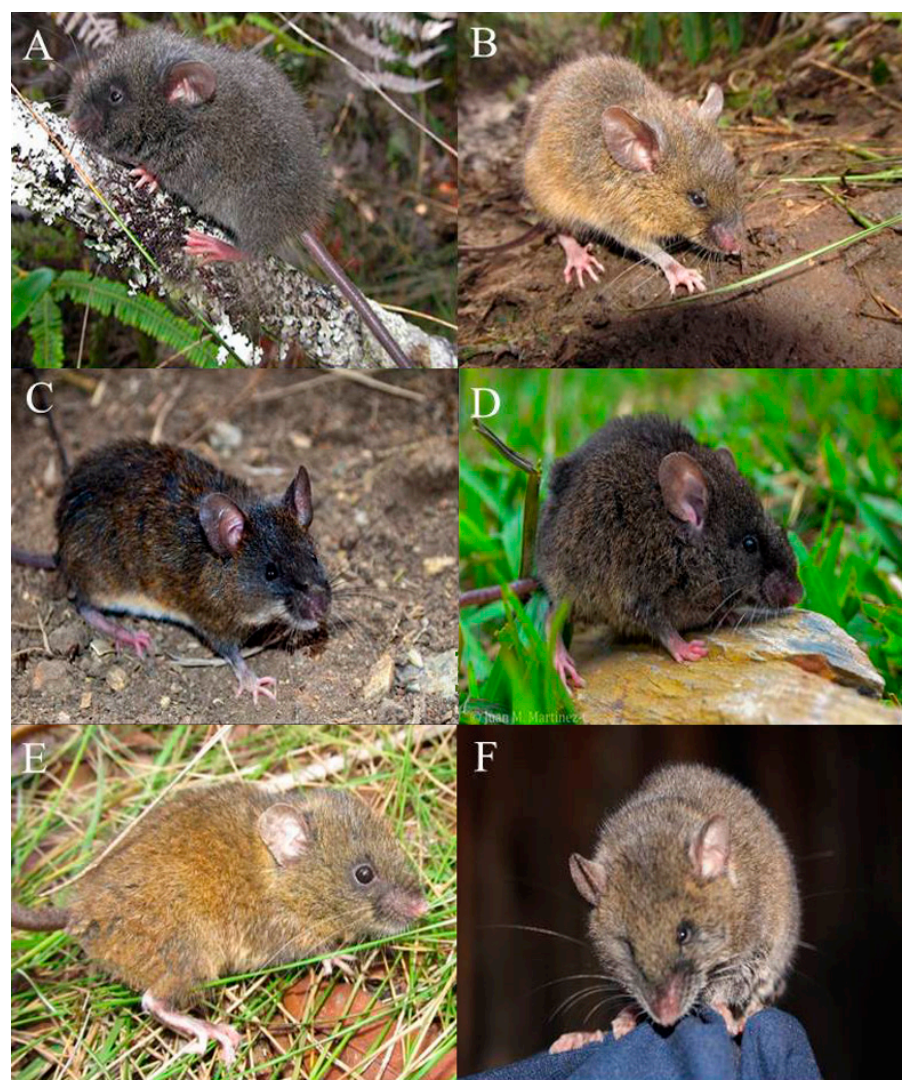

Figure 2. Some of the species recorded in the sampling of Andean rodents. Top row, Chilomys instans (A), Nephelomys childi (B); middle row, N. pectoralis (C), Handleyomys fuscatus (D); bottom row, Thomasomys cinnameus (E), and T. cinereiventer (F). 


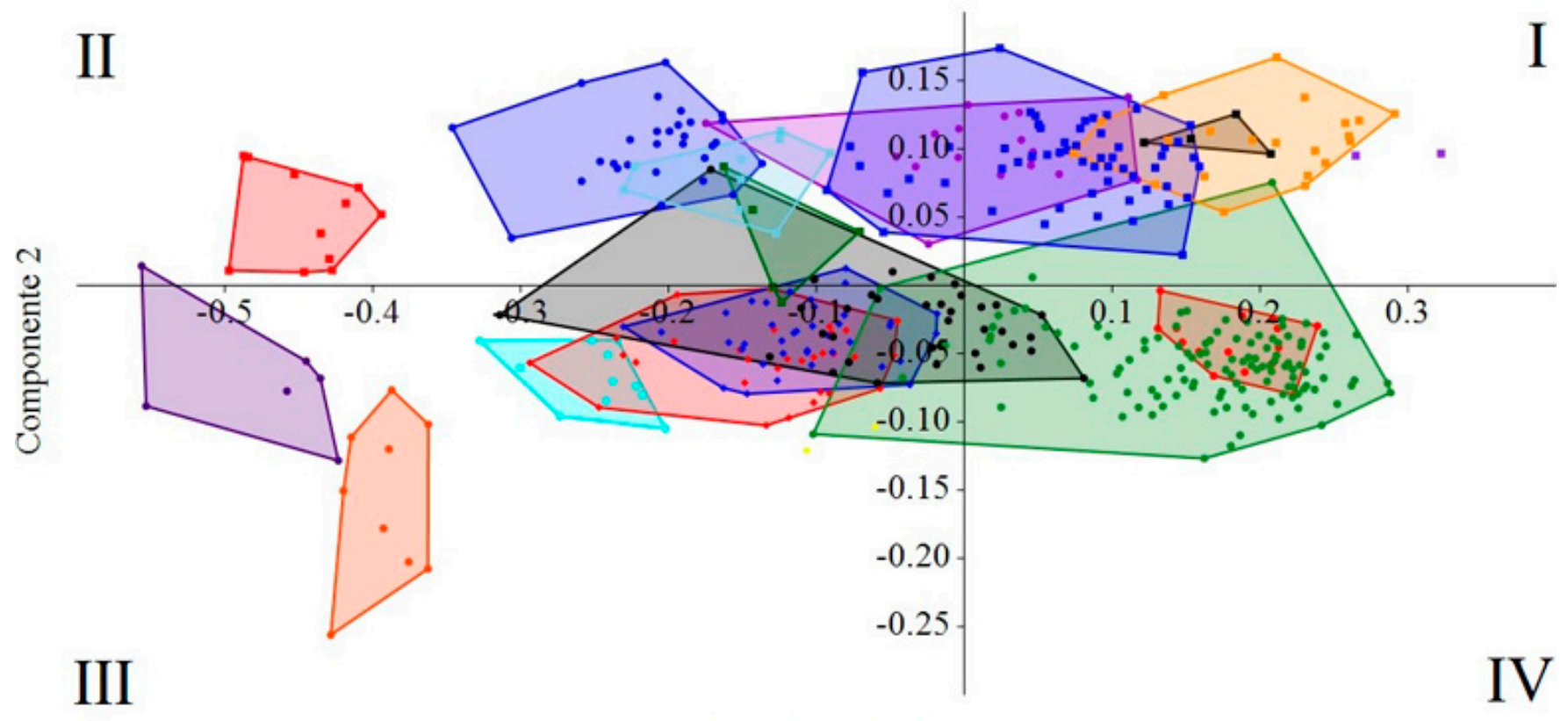

\section{Componente 1}

Figure 3. Scatterplot of species in the hyperdimensional space represented by $\mathrm{CP} 1$ and $\mathrm{CP} 2$ for the total data. Color polygons identify the clustering patterns of species; symbols and colors correspond to: $A$. affinis = blue dot, $C$. instans = light blue dot, H. alfaroi = yellow diamond, H. fuscatus = red diamond, H. intectus = blue diamond, $M$. caliginosus $=$ black dot,

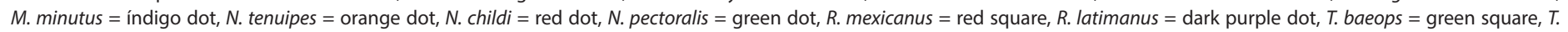
cinereiventer $=$ black square, T. cinnameus $=$ light blue square, $T$. contradictus $=$ blue square, $T$. nicefori $=$ dark orange square, . . popayanus $=$ purple-blue square.

the higher richness in terms of species and number of individuals. These were: Belmira (8 spp., 59 specimens), La Mesenia (7 spp., 40 specimens), Medellín (7 spp., 39 specimens), Sonsón (7 spp., 33 specimens), and Manizales (7 spp., 32 specimens).

Belmira. This locality, in the Central Cordillera $\left(6.7072^{\circ} \mathrm{N}\right.$, $-75.6888^{\circ} \mathrm{W}$ ) and with elevations between 2,900 and 3,050 $m$, included a total of eight species that represented five of the morphogroups defined above: (A) M. minutus, $R$. mexicanus, (B) A. affinis, T. baeops, T. cinnameus, (D) T. contradictus, (E-I) T. nicefori, and (E-IV) N. pectoralis. The PCA reveals that the first three components account for $94.2 \%$ of the variation; this value is partitioned into $86.4 \%$ for CP1, $4.8 \%$ for $\mathrm{CP} 2$, and $3.0 \%$ for CP3. Figure 5 a presents the morphospace determined by the first two components.

La Mesenia. Located in the Central Cordillera (5.5254 $\mathrm{N},-75.9294^{\circ} \mathrm{W}$ ) and with elevations around 2,350 m; seven species were recorded, representing five of the morphogroups defined above: (B) A. affinis, R. latimanus, (C) H. fuscatus, M. caliginosus, (D) T. cinereiventer, (E-I) T. popayanus, and (E-IV) N. pectoralis. In the PCA for this locality, the first three components account for $91.8 \%$ of the variation: $82.0 \%$ for CP1, 6.2 \% for CP2, and 3.6\% for CP3. The scatter plot determined by the first two components is shown in Figure $5 \mathrm{~b}$.

Medellin. Located in the Central Cordillera $\left(6.2082^{\circ} \mathrm{N}\right.$, $-75.6480^{\circ} \mathrm{W}$ ) with elevations above $2,300 \mathrm{~m}$; seven species were recorded, representing all the morphogroups previously defined: (A) M. minutus, (B) A. affinis, (C) H. intectus, $M$. caliginosus, (D) T. contradictus, (E-I) T. nicefori, and (E-IV) N. pectoralis. The PCA reveals that the first three components account for $94.4 \%$ of the total variation: $84.6 \%$ for CP1, 6.9 $\%$ for $\mathrm{CP} 2$, and $2.9 \%$ for $\mathrm{CP} 3$.
Sonsón. Located in the Central Cordillera $\left(5.7182^{\circ} \mathrm{N}\right.$, $-75.2469^{\circ} \mathrm{W}$ ) and with elevations above $2,050 \mathrm{~m}$; seven species were recorded, representing all the morphogroups defined above: (A) N. tenuipes, (B) R. latimanus, T. cinnameus, (C) C. instans, (D) T. contradictus, (E-I) T. nicefori, and (E-IV) N. childi. This PCA reveals that the first three components account for $95.6 \%$ of the variation: $82.9 \%$ for $\mathrm{CP} 1,9.1 \%$ for $\mathrm{CP} 2$, and $3.5 \%$ for $\mathrm{CP} 3$.

Manizales. Located in the Central Cordillera $\left(5.0838^{\circ} \mathrm{N}\right.$, $-75.4230^{\circ} \mathrm{W}$ ) and with elevations of $2,550 \mathrm{~m}$; seven species were recorded, representing all the morphogroups defined above: (A) R. mexicanus, (B) A. affinis, T. baeops, (C) C. instans, (D) T. contradictus, (E-I) T. nicefori, and (E-IV) N. pectoralis. The PCA for this locality indicates that the first three com-

Table 2. Geographical origin of specimens and number of species (\# SPP) and individuals in each locality. The asterisk indicates the localities selected for the individual analysis.

\begin{tabular}{cccc}
\hline Department & Regional Unit & \# SPP & \# Specimens \\
\hline Antioquia & Aburrá Norte & 7 & 30 \\
Antioquia & Aburrá Sur & 4 & 36 \\
Antioquia & Amalfi & 5 & 41 \\
Antioquia & Anorí & 4 & 18 \\
Antioquia & Belmira* & 8 & 59 \\
Tolima & Cajamarca & 4 & 9 \\
Antioquia & Ebéjico & 3 & 9 \\
Antioquia & Guanacas & 4 & 11 \\
Antioquia & Jardín-Támesis & 6 & 35 \\
Antioquia & La Mesenia* & 7 & 40 \\
Caldas & Manizales* & 7 & 32 \\
Antioquia & Medellín* & 7 & 39 \\
Antioquia & Sonsón* & 7 & 33 \\
Antioquia & Yarumal & 6 & 32 \\
& & Total & $\mathbf{4 2 4}$
\end{tabular}



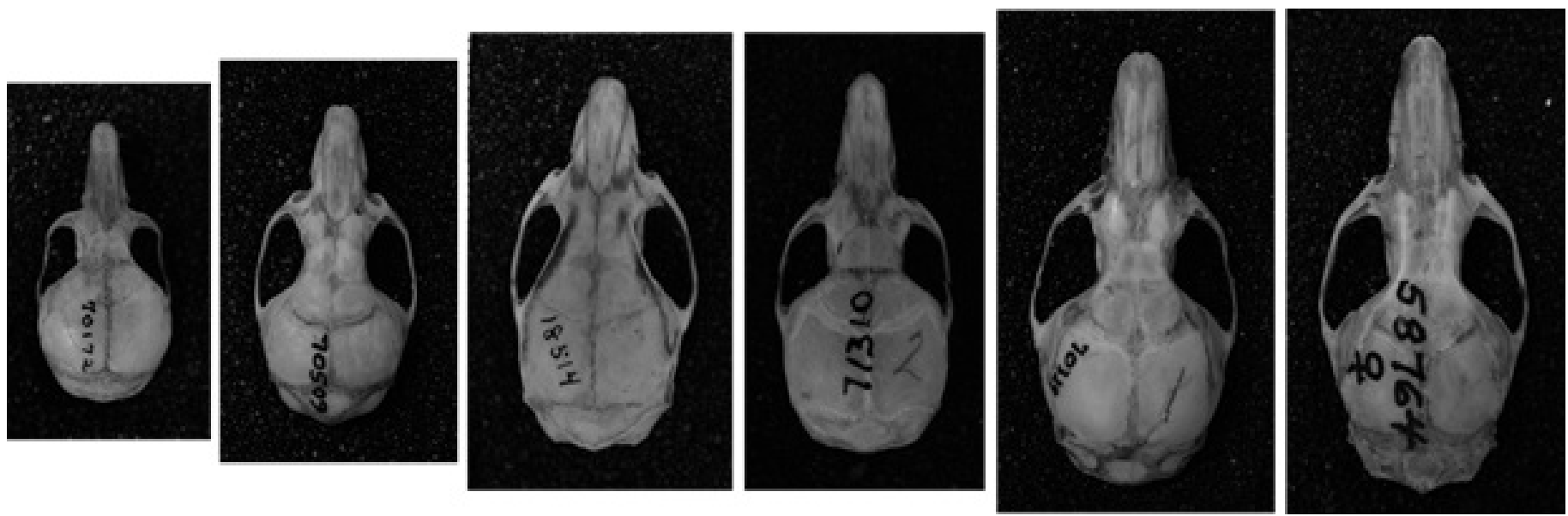

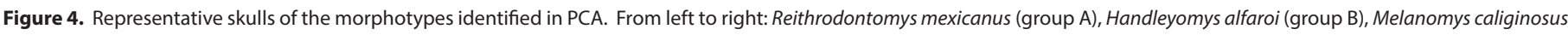

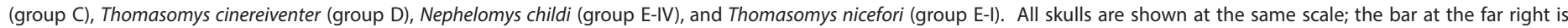
equivalent to $20 \mathrm{~mm}$.

ponents account for $92.7 \%$ of the variation: $83.3 \%$ for CP1, $5.3 \%$ for $\mathrm{CP} 2$, and $4.1 \%$ for $\mathrm{CP} 3$.

\section{Discussion}

In general, among the local assemblages of high-Andean rodents of Antioquia, a species arrangement model can be seen where there are differences in the size and shape of the species (skull morphometry), a pattern that can be corroborated in the scatter plots (Figures 3, and 5), as well as in the analysis of loads (factorial coefficients) of the relevant variables for each component. With regard to the first aspect, cricetids are characterized by morphotypes associated with different trophic niches (Pizzimenti and De Salle 1980), many of which are presented in this analysis and are distributed across the space defined by the first two main components. This separation was further evidenced when local communities were analyzed, with the few species (seven to eight) being segregated in a differential way between the various assemblages (Figure 5).

Table 3. Table of the factorial coefficients associated with the first three components of the analysis of total assemblages. Autovalues and the percentage of variance represented by each component are shown. The acronyms used are indicated in the Methodology section.

\begin{tabular}{lrrr}
\hline & PC 1 & PC 2 & \multicolumn{1}{c}{ PC 3 } \\
\hline Autovalue & 0.03505 & 0.00610 & 0.00556 \\
\% variance & 63.91500 & 11.14000 & 10.13900 \\
CIL & 0.33294 & -0.00060 & 0.09756 \\
AC & 0.32851 & 0.01370 & 0.09588 \\
MW & 0.19170 & 0.14343 & 0.04610 \\
MIC & 0.13317 & 0.20142 & 0.02826 \\
RL & 0.37792 & 0.12214 & -0.23732 \\
NL & 0.01302 & -0.09495 & 0.04311 \\
AW & 0.03362 & -0.17398 & 0.10504 \\
OL & 0.05159 & -0.14544 & 0.38551 \\
DL & 0.03166 & -0.07770 & 0.22653 \\
ML & 0.04031 & 0.02358 & 0.35136 \\
IFL & -0.00186 & 0.61348 & 0.61249 \\
PBL & 0.04160 & -0.16231 & 0.27053 \\
AW & 0.40041 & 0.18061 & -0.07788 \\
MFW & 0.39964 & 0.32658 & -0.29473 \\
ZPW & 0.50553 & -0.56102 & 0.21095 \\
\hline
\end{tabular}

When the presence of these six morphogroups was analyzed, as defined by the PCA at a regional scale, it is evident that there is zero to minimal overlap in the morphometric space between species at the local scale, although this is also a consequence of a lower representativeness in the number of species (with a maximum of eight in Belmira and La Mesenia). However, it is remarkable that all morphogroups occur in the localities with fewer species (seven). It should be noted that the majority of these morphogroups do not correspond to taxonomic divisions, and that these divisions do not behave as a single unit with regard to morphology.

However, in the scatter plot of the regional assemblage this pattern should not be interpreted in a manner similar to the local one, since the inclusion of the whole sample in a single analysis results in the overlap between species within the same morphogroup (e. g., N. childi and N. pectoralis; Figure 3). Since some authors (Pianka 1973, Gotelli and Ellison 2002; Adams 2007) point to that a wide competition would not be favored in natural assemblages, this co-occurrence would indicate that other factors are acting at the level of that assemblage. However, as recorded in our sampling and other studies (Percequillo 2003), these two species are not sympatric. In contrast, sympatry may occur in some cases, such as in Belmira with T. baeops and $T$. cinnameus (Figure 5a), which would indicate that additional factors would be offsetting the potential competition (for example, character displacement).

Among the variables analyzed, there are five (ZPW, MFW, IFL, ML and RW; Table 4) that account for most of the variation in the overall analysis and the individual analyses, while at the same time, four others $(\mathrm{CIL}, \mathrm{ZW}, \mathrm{MW}$ and $\mathrm{PBL}$ ) did not contribute significantly in any PCA of these localities (therefore, these are not shown). In this way, the arrangement of morphometric variables would allow inferring an ecological separation of species, as evidenced in the morphogroups identified. Although these variables are not directly related to size as such, these could play a key role in the segregation of resources between species from an anatomical point of view (Landry 1970), determining muscular 

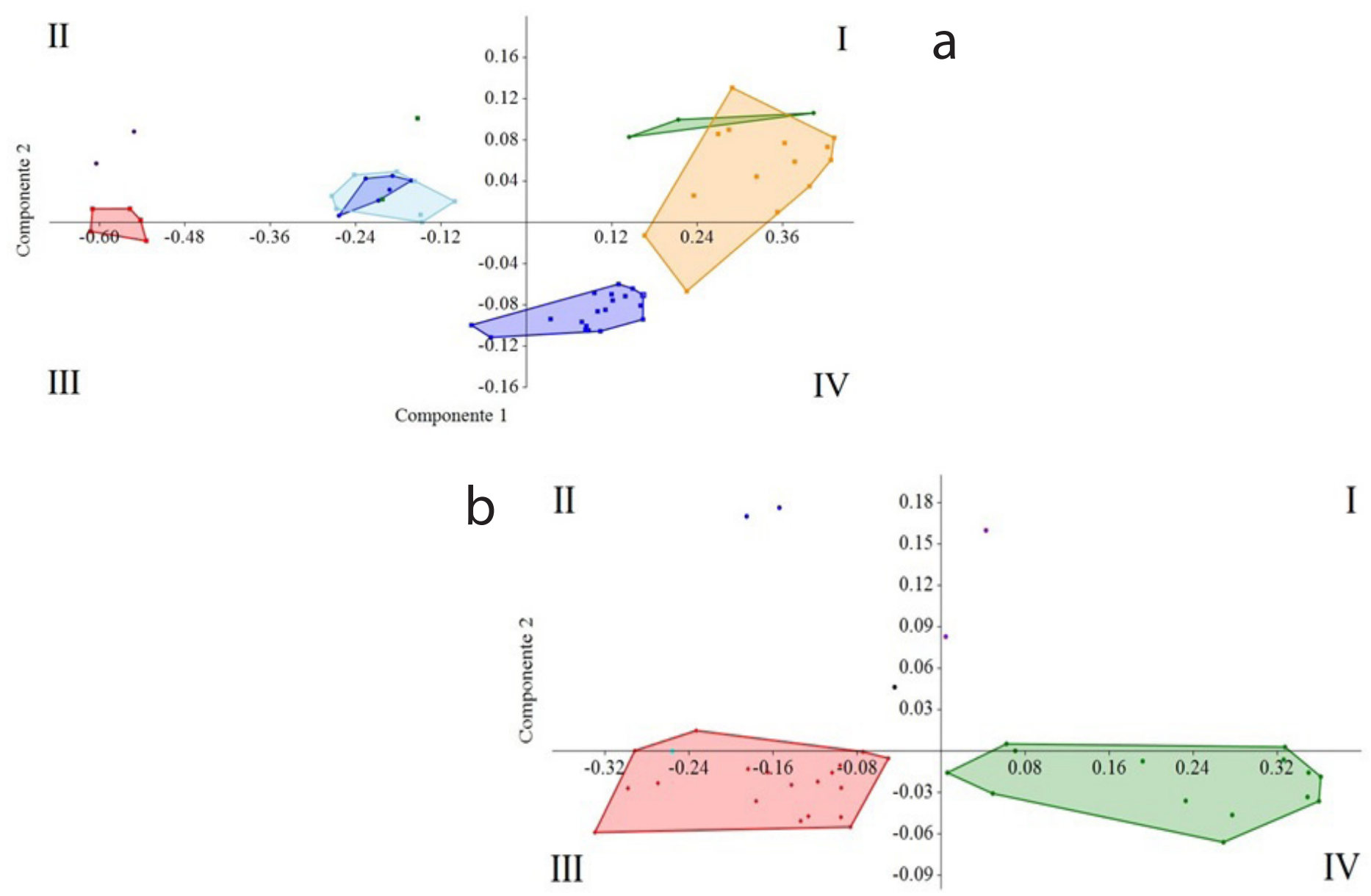

Figure 5. Scatterplot of the species recorded in some local assemblages shown in the hyperdimensional space represented by CP1 and CP2. Symbols and colors are as in Figure 3. (a) Belmira, Central Cordillera, (b) La Mesenia, Western Cordillera.

insertions (ZPW) or passage of food to the digestive tube (MFW). In a study of the rodent Peromyscus zarhynchus, Lorenzo et al. (2006) suggest that morphometric differences between geographical populations seem to be influenced by the variation in the type of food available in these areas. Gould (1966) mentions that evolutionary allometry represents real temporal changes of ratios within a genetic continuum; due to the relationship between these shape, ecological segregation can function as a mechanism favoring differences between species of the same genus, even before promoting geographical isolation. Further studies with a greater emphasis on ecomorphological aspects could unveil the role of these variables in the segregation between species. Likewise, other aspects should also be

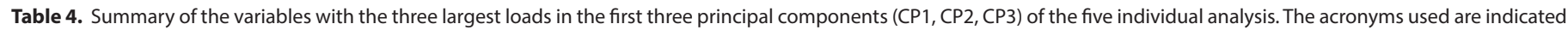
in the Methodology section.

\begin{tabular}{|c|c|c|c|c|c|c|c|c|c|c|c|c|c|c|c|}
\hline & \multicolumn{3}{|l|}{ Belmira } & \multicolumn{3}{|c|}{ La Mesenia } & \multicolumn{3}{|l|}{ Medellín } & \multicolumn{3}{|l|}{ Sonsón } & \multicolumn{3}{|c|}{ Manizales } \\
\hline & $\mathrm{CP} 1$ & $\mathrm{CP} 2$ & $\mathrm{CP} 3$ & $\mathrm{CP} 1$ & $\mathrm{CP} 2$ & $\mathrm{CP} 3$ & $\mathrm{CP} 1$ & $\mathrm{CP} 2$ & $\mathrm{CP} 3$ & $\mathrm{CP} 1$ & $\mathrm{CP} 2$ & $\mathrm{CP} 3$ & $\mathrm{CP} 1$ & $\mathrm{CP} 2$ & $\mathrm{CP} 3$ \\
\hline MIC & & & & & & -0.209 & & 0.187 & & & 0.414 & & & & \\
\hline $\mathrm{RL}$ & & & & & & & & & & & & & 0.338 & & \\
\hline NL & & & & & & 0.309 & & & & & & & 0.345 & & \\
\hline AW & & & -0.292 & & -0.149 & & & & 0.536 & & & -0.248 & & -0.397 & \\
\hline $\mathrm{OL}$ & & & & 0.310 & & & & & & & & & & & \\
\hline $\mathrm{DL}$ & & & & & & & 0.302 & & & & & & & & 0.234 \\
\hline ML & 0.339 & & & 0.300 & & & & & & 0.334 & & & & 0.618 & \\
\hline IFL & & 0.380 & 0.743 & & 0.796 & & & 0.727 & -0.472 & & & 0.696 & & 0.6189 & \\
\hline AW & 0.324 & & & & & & & & & & & & & & \\
\hline MFW & & -0.472 & & & & 0.802 & 0.311 & & 0.486 & 0.322 & 0.360 & -0.521 & 0.451 & & -0.250 \\
\hline ZPW & 0.322 & 0.465 & -0.516 & 0.390 & -0.505 & & 0.346 & -0.612 & & 0.343 & -0.689 & & & & 0.786 \\
\hline
\end{tabular}


considered, such as diet at the local level (see Pizzimenti and De Salle 1980; Giménez and Giannini 2011), selection of specific microhabitats (Vitt et al. 2000), and evolutionary relationships between species, to understand the dynamics and organization of these assemblages.

Although the procedure of combining localities that are geographically close allowed to obtain some interesting approximations, in the long term it is recommended to include only localities with sufficiently comprehensive sampling to elucidate the complex of rodents inhabiting these Andean forests. Methodologically, combining undersampled localities can lead to further error in the analysis, or may confound the actual assemblage patterns. For example, localities such as La Mesenia (Western Cordillera) or Belmira (Central Cordillera) have comparable numbers of species and individuals, revealing patterns not only regarding presence but also abundance, which would be more informative to raise additional questions to this study.

Localities sampled evenly can also contribute to the knowledge of geographic patterns for species, which in many cases show discontinuities not attributable to any geographical or ecological barrier. For instance, we found that $N$. pectoralis was collected in four of the five individual localities, but its distribution is interrupted by its sister species N. childi, which was recorded only in Sonsón. In other cases, there are species that do not occur in both cordilleras, outlining a biogeographical exclusion pattern (Voss et al. 2002; Pacheco 2003; Percequillo 2003). Such is the case of some species of Thomasomys; for example, T. popayanus and T. cinereiventer in the Western Cordillera; and T. baeops, $T$. contradictus, T. cinnameus, and T. nicefori in the Central Cordillera. However, the lack of sampling rigor precludes the detection of a real pattern, since there are rare species that can only be captured in specific microhabitats or after intense sampling (Sánchez-Giraldo and Díaz-Nieto 2015).

In addition, there are still information gaps on the ecology of high-Andean rodents in Colombia, especially regarding diet-related topics (Montenegro-Díaz et al. 1991; LopezArevalo et al. 1993; Solari 2007), which considerably reduces the resolution power of this approximation. Likewise, we must take into account the restricted distribution of some of the species included in the analyses. For example, the genera Handleyomys, Nephelomys and Thomasomys show pairs of similar species with an allopatric distribution (Voss et al. 2002; Pacheco 2003; Percequillo 2003). However, this gap is likely influenced also by their taxonomic closeness, making it difficult to find species with very similar morphology in the same locality (Bowers and Brown 1982, Gotelli and Ellison 2002).

These fundamental factors influence assemblage rules, so it was not possible to demonstrate a structure that is maintained from the regional scale to that of local assemblages. Besides, the geographical isolation of the various assemblages may result in different combinations of species and particular relationships within the morphometric space. In this sense, although ecomorphological analyses are an effective tool for understanding the assemblages and organization in a community (Pizzimenti and De Salle 1980; Ricklefs and Travis 1980; Arita 1997; Moreno et al. 2006; Giménez and Giannini 2011), these were not conclusive in this particular case. However, this first approximation shows the usefulness of regional studies to understand patterns of species diversity and replacement, which should be supplemented by analyses of ecological aspects such as diet composition, microhabitat, foraging strategies, and periods of activity (Bruseo and Barry 1995; Arita 1997; Vitt et al. 2000) to interpret the coexistence of various species in a local assemblage.

\section{Acknowledgments}

This study received funding from the National Geographic Society - Waitt Grants (W31-08) and the Vicerrectoría de Investigación at the University of Antioquia, 2011 and 2012. The first author thanks the Mastozoology Group and the Colección Teriológica, University of Antioquia, for welcoming him to the wonderful world of mammals, for their support and patience. We are grateful to C. SánchezGiraldo and J.M. Martinez for their comments and suggestions, and to the latter for the elaboration of the map and sharing some photographs (N. pectoralis, H. fuscatus). Also, D. Marín (photographs of $C$. instans and N. childi), T. Villada (photograph of T. cinereiventer) and S. Botero (T. cinnameus) for facilitating some specimen photographs. We thank D. Zurc for her final edition of the figures. In addition, to the colleagues who participated in field sampling, to the institutions, managers (Corantioquia, Fundación Guanacas, La Mesenia-Paramillo Reserve, the regional office of the $U$. de Antioquia at Sonsón) and to the inhabitants of the locations where we conducted this study. Finally, to the reviewers of the manuscript for their comments and suggestions that improved the quality of this work. María Elena SánchezSalazar translated this manuscript into English.

\section{Literature cited}

AdAms, D. C. 2007. Organization of Pletodon salamander communities: guild-based community assembly. Ecology 88:1292-1299.

ARITA, H. T. 1997. Species composition and morphological structure of the bat fauna of Yucatan, Mexico. Journal of Animal Ecology 66:83-97.

Bowers, M. A., AND J. H. Brown. 1982. Body size and coexistence in desert rodents: chance or community structure? Ecology 63:391-400.

Bruseo, J. A., AND R. E. Barry. 1995. Temporal activity of syntopic Peromyscus in the Central Appalachians. Journal of Mammalogy 76:78-82.

Connor, E. F., AND D. Simberloff. 1979. The Assembly of Species Communities: Chance or Competition? Ecology 60:11321140.

CRISCI, J. V., AND M. F. López-A. 1983. Introducción a la teoría y práctica de la taxonomía numérica. Secretaría General de la Organización de Estados Americanos (OEA). Washington, U S. A. 
DiAmond, J. M. 1975. Assembly of species communities. Pp. 342-444, in Ecology and evolution of communities (Cody, M., and J. M. Diamond, eds.). Harvard University Press. Cambridge, U S. A.

Fauth, J. E., J. Bernardo, M. Camara, W. J. Resetarits, J. Van Buskirk, AND S. A. McCollum. 1996. Simplifying the jargon of community ecology: a conceptual approach. The American Naturalist 147:282-286.

FINDLEY, J. S. 1975. The structure of bat communities. The American Naturalist 110:129-139.

Freeman, P. W. 1998. Form, function, and evolution in skulls and teeth of bats. Pp. 140-156, in Bat Biology and Conservation (Kunz, T. H. and P. A. Racey, eds.). Smithsonian Institution Press. Washington, USA.

Freeman, P. W. 1981. A multivariate study of the family Molossidae (Mammalia, Chiroptera): morphology, ecology, evolution. Fieldiana, Zoology, new series 7:1-173.

GIMÉNEZ, A., AND N. GIANNINI. 2011. Morphological and geographic segregation among species of lasiurine bats (Chiroptera: Vespertilionidae) from the South American southern cone. Mammalia 75:173-179.

Gómez-Valencia, B. 2006. Estructura de la comunidad de pequeños mamíferos en un gradiente altitudinal, Reserva Río Blanco, Manizales, Caldas, Colombia [Trabajo de pregrado]. Universidad Nacional de Colombia. Bogotá, Colombia.

Gotelli, N. J., AND A. M. Ellison. 2002. Assembly rules for New England ant communities. Oikos 99:591-599.

GouLD, S. J. 1966. Allometry and size in ontogeny and phylogeny. Biological Reviews 41:587-640.

Hammer, Ø., D. A. HarPer, ANd P.D. Ryan. 2001. PAST:Paleontological statistics software package for education and data analysis. Palaeontologia Electronica 4:9.

James, F. C., And C. E. McCulloch. 1990. Multivariate Analysis in Ecology and Systematics: Panacea or Pandora's Box? Annual Review of Ecology and Systematics 21:129-166.

JACKSON, D. A. 1993. Stopping rules in principal components analysis: a comparison of heuristical and statistical approach. Ecology 74:2204-2214.

LANDRY, S. 1970. The Rodentia as omnivores. The Quarterly Review of Biology 45:351-372.

López-Arévalo, H., O. Montenegro-Díaz, and A. Cadena. 1993. Ecología de los pequeños mamíferos de la Reserva Biológica Carpanta, en la Cordillera Oriental colombiana. Studies on Neotropical Fauna and Environment 28:93-210.

Lorenzo, C., L. Cuautle, E. Espinoza, and M. García. 2006. Intraspecific variation in Peromyscus zarhynchus (Rodentia: Muridae) from Chiapas, Mexico. Journal of Mammalogy 87:683-689.

Montenegro-Díaz, O., H. López-Arévalo, and A. Cadena. 1991. Aspectos ecológicos del roedor arborícola Rhipidomys latimanus Tomes, 1860 (Rodentia, Cricetidae) en el oriente de Cundinamarca, Colombia. Caldasia 16:565-572.

Moreno, C. E., H. T. AritA, And L. Solis. 2006. Morphological assembly mechanisms in Neotropical bat assemblages and ensembles within a landscape. Oecologia 149:133-140.

Muñoz-Saba, Y., J. O. Rangel, and A. Cadena. 2000. Mamíferos. Pp. 599-611, in Colombia: Diversidad Biótica III. La Región de vida Paramuna (Rangel, J.O., ed.). Universidad Nacional de Colombia. Bogotá, Colombia.
Norman, G. R., And D. L. Streiner. 1996. Bioestadística. Harcourt Brace, Edición en español. Madrid, España.

Otarola-Ardila, A. 2003. Mamíferos de los bosques de roble. Acta Biológica Colombiana 8:57-71.

PACHECO, V. 2003. Phylogenetic Analyses of the Thomasomyini (Muroidea Sigmodontinae) based on morphological data [Doctoral dissertation]. The City University of New York. New York, USA.

Patterson, B. D. 1999. Contingency and determinism in mammalian biogeography: the role of history. Journal of Mammalogy 80:345-360.

Patton, J. L., M. N. F. da Silva, And J. R. Malcolm. 2000. Mammals of the Rio Juruá and the evolutionary and ecological diversification of Amazonia. Bulletin of the American Museum of Natural History 244:1-306.

Patton, J. L., U. F. PardiñAs, AND G. D'Elía. 2015. Mammals of South America, Volume 2: Rodents. University of Chicago Press. Chicago, U S. A.

Percequillo, A. R. 2003. Sistemática de Oryzomys Baird, 1858: definição dos grupos de espécies e revisão taxonômica do grupo albigularis (Rodentia, Sigmodontinae) [Doctoral dissertation]. Universidade de São Paulo. São Paulo, Brasil.

Peres-Neto, P. R., D. A. Jackson, and K. M. Somers. 2003. Giving meaningful interpretation to ordination axes: assessing loading significance in principal component analysis. Ecology 84:2347-2363.

PiankA, E. R. 1973. The structure of lizard communities. Annual Review of Ecology and Systematics 4:53-74.

PizzimentI, J. J., AND R. DE SAlle. 1980. Dietary and morphometric variation in some Peruvian rodent communities: the effect of feeding strategy on evolution. Biological Journal of the Linnean Society 13:263-285.

Ricklefs, R. E., AND J. TRAVIS. 1980. A morphological approach to the study of avian community organization. The Auk 97:321-338.

Sánchez, F., P. Sánchez-Palomino, and A. Cadena. 2004. Inventario de mamíferos en un bosque de los Andes centrales de Colombia. Caldasia 26: 291-309.

Sánchez-Giraldo, C., and J. F. Díaz-Nieto. 2015. Dynamics of species composition of small nonvolant mammals from the northern Cordillera Central of Colombia. Mammalia 79:385-397.

SolARI, S. 2007. Trophic relationships in a highland rodent assemblage of Manu National Park, Cusco, Peru. Pp. 225-240, in The Quintessential Naturalist: honoring the Life and Legacy of Oliver P. Pearson (Kelt, D.A., E. Lessa, J. Salazar-Bravo, and J. L. Patton, eds.). University of California Publications in Zoology, 134. University of California Press. Los Angeles, U S. A.

Soriano, P., A. Díaz de Pascual, J. Ochoa, and M. Aguilera. 1999. Las comunidades de roedores de los Andes Venezolanos. Acta Zoológica Mexicana, volumen especial 1998:211-226

Viancha-Sánchez, A., J. Cepeda-Gómez, E. Muñoz-López, A. HernándezOChoA, AND L. Rosero-Lasprilla. 2012. Mamíferos pequeños no voladores del Parque Natural Municipal Ranchería, Paipa, Boyacá, Colombia. Revista Biodiversidad Neotropical 2:37-44. Vitt, L. J., S. S. Sartorius, T. S. C. Avila-Pires, M. C. Esposito, and D. B. MiLES. 2000. Niche segregation among sympatric Amazonian teiid lizards. Oecologia 122:410-420.

Voss, R. S. 2003. A new species of Thomasomys (Rodentia: Muridae) from Eastern Ecuador with remarks on mammalian 
diversity and biogeography in the Cordillera Oriental. American Museum Novitates 3421:1-47.

Voss, R. S., M. Gómez-Laverde, AND V. Pacheco. 2002. A new genus for Aepeomys fuscus Allen, 1912, and Oryzomys insectus Thomas, 1921: enigmatic Murid rodents from the Andean cloud forest. American Museum Novitates 3373:1-42.

Voss, R. S., D. P. Lunde D. P., AND N. B. Simmons. 2001. The mammals of Paracou, French Guiana: a Neotropical lowland rainforest fauna Part 2. Nonvolant species. Bulletin of the American Museum of Natural History 263:1-236.

Weksler, M. 2006. Phylogenetic relationships of Oryzomyine rodents (Muroidea: Sigmodontinae): separate and combined analyses of morphological and molecular data. Bulletin of the American Museum of Natural History 296:1-149.

WeksLer, M., AND A. R. Percequillo. 2011. Key to the genera of the tribe Oryzomyini (Rodentia: Cricetidae: Sigmodontinae). Mastozoología Neotropical 18:281-292.

WILLIG, M. R. 1986. Bat community structure in South America: a tenacious chimera. Revista Chilena de Historia Natural 52:151-168.

WILLIG, M. R., AND M. P. Moulton. 1989. The role of stochastic and deterministic processes in structuring Neotropical bat communities. Journal of Mammalogy 70:323-329.

Associated editor: Consuelo Lorenzo

Submitted: November 15, 2016; Reviewed: December 14, 2016;

Accepted: January 24, 2017; Published on line January 30, 2017. 